\title{
Double-blind, randomized, placebo-controlled study of trofinetide in pediatric Rett syndrome
}

Daniel G. Glaze, MD, * Jeffrey L. Neul, MD, PhD, * Walter E. Kaufmann, MD,* Elizabeth Berry-Kravis, MD, PhD, Sean Condon, DPH, George Stoms, BS, Sean Oosterholt, MSc, Oscar Della Pasqua, MD, PhD, Larry Glass, BA, Nancy E. Jones, PhD, and Alan K. Percy, MD,* on behalf of the Rett 002 Study Group

Neurology ${ }^{\circledR}$ 2019;92:e1912-e1925. doi:10.1212/WNL.0000000000007316

\section{Abstract}

\section{Objective}

To determine safety, tolerability, and pharmacokinetics of trofinetide and evaluate its efficacy in female children/adolescents with Rett syndrome (RTT), a debilitating neurodevelopmental condition for which no pharmacotherapies directed at core features are available.

\section{Methods}

This was a phase 2, multicenter, double-blind, placebo-controlled, parallel-group study, in which safety/tolerability, pharmacokinetics, and clinical response to trofinetide were characterized in 82 children/adolescents with RTT, aged 5 to 15 years. Sixty-two participants were randomized 1:1:1:1 to receive placebo twice a day (bid) for 14 days, followed by placebo, 50, 100, or $200 \mathrm{mg} / \mathrm{kg}$ bid of trofinetide for 42 days. Following blinded safety data review, 20 additional participants were randomized $1: 1$ to the $200 \mathrm{mg} / \mathrm{kg}$ or placebo bid groups. Safety assessments included adverse events, clinical laboratory tests, physical examinations, and concomitant medications. Clinician- and caregiver-based efficacy measurements assessed clinically relevant, phenotypic dimensions of impairment of RTT.

\section{Results}

All dose levels were well tolerated and generally safe. Trofinetide at $200 \mathrm{mg} / \mathrm{kg}$ bid showed statistically significant and clinically relevant improvements relative to placebo on the Rett Syndrome Behaviour Questionnaire, RTT-Clinician Domain Specific Concerns-Visual Analog Scale, and Clinical Global Impression Scale-Improvement. Exploratory analyses suggested that observed changes correlated with trofinetide exposure.

\section{Conclusion}

These results, together with those from a previous adolescent/adult trial, indicate trofinetide's potential for treating core RTT symptoms and support further trials.

\section{Classification of evidence}

This study provides Class I evidence that for children/adolescents with RTT, trofinetide was safe, well-tolerated, and demonstrated improvement over placebo at $200 \mathrm{mg} / \mathrm{kg}$ bid in functionally important dimensions of RTT.

\author{
Correspondence \\ Dr. Jones \\ njones@neurenpharma.com
}

\section{RELATED ARTICLE}

\section{Editorial}

Turning the tide on targeted treatments for neurodevelopmental disorders

Page 741

MORE ONLINE

$\rightarrow$ Class of Evidence

Criteria for rating

therapeutic and diagnostic studies

NPub.org/coe

- CME Course

NPub.org/cmelist

\footnotetext{
*These authors made equal contributions to the conduct and/or analysis of the study described in this manuscript.

From the Department of Pediatrics and Neurology (D.G.G.), Baylor College of Medicine, Houston, TX; Department of Neurosciences (J.L.N.), University of California, San Diego; Greenwood Genetic Center (W.E.K.), Center for Translational Research, Greenwood, SC; Pediatrics, Neurological Sciences, and Biochemistry (E.B.K.), Rush University Medical Center, Chicago, IL;Vital Systems, Inc. (S.C., G.S.), Rolling Meadows, IL; Clinical Pharmacology \& Therapeutics Group (S.O., O.D.P.), University College London, UK; Neuren Pharmaceuticals, Ltd. (L.G., N.E.J.), Camberwell, VIC, Australia; Department of Pediatrics (A.K.P.), Division of Neurology, University of Alabama at Birmingham. J.L.N. is currently affiliated with the Vanderbilt University Medical Center, Vanderbilt Kennedy Center, Nashville, TN.

Go to Neurology.org/N for full disclosures. Funding information and disclosures deemed relevant by the authors, if any, are provided at the end of the article.

The Article Processing Charge was funded by ACADIA Pharmaceuticals Inc. and Neuren Pharmaceuticals Limited.
} 


\section{Glossary}

$\mathbf{A E}=$ adverse event AUC $=$ area under the concentration vs time curve; bid $=$ twice a day; CGI-I = Clinical Global Impression Scale-Improvement; IGF1 = insulinlike growth factor 1; IRB = institutional review board; ITT = intention to treat; $\mathbf{M B A}=$ Motor Behavioral Assessment; mITT $=$ modified intention to treat; PK $=$ pharmacokinetic; PKPD $=$ pharmacokineticpharmacodynamic; RSBQ = Rett Syndrome Behaviour Questionnaire; RTT = Rett syndrome; RTT-DSC = Rett syndrome-Clinician Domain Specific Concerns; SAE = serious adverse event; VAS = Visual Analog Scale.

Rett syndrome (RTT) is a neurodevelopmental disorder affecting 1 in 10,000-15,000 females. ${ }^{1-4}$ Most cases are caused by loss of function mutations in the X-linked gene, methylCpG-binding protein 2 (MECP2), ${ }^{5,6}$ encoding a protein that binds to DNA and regulates transcription. ${ }^{6-8}$

RTT is characterized by developmental regression including loss of expressive language and purposeful hand use, impaired or absent ambulation, and onset of stereotypical hand movements. ${ }^{9}$ Individuals with RTT have severe motor deficits and autonomic, gastrointestinal, and other systemic symptoms. ${ }^{10}$ Neurobehavioral impairments are prevalent, including anxiety-like behaviors, disruptive behavior, and mood dysregulation. ${ }^{11-14}$ Disease burden is severe for individuals and their families, the effects of which are lifelong. ${ }^{15,16}$ No approved or effective treatment is available for the core or other prevalent symptoms of RTT.

Trofinetide (glycyl-L-2-methylprolyl-L-glutamic acid) is an analog of the amino-terminal tripeptide of insulinlike growth factor 1 (IGF1 [1-3]). RTT mouse models demonstrated that IGF1 (1-3) treatment improves disease symptoms. ${ }^{17}$ Trofinetide is believed to have potential in treating RTT by normalizing aberrant neuronal and glial function secondary to anti-inflammatory and trophic effects, which inhibit astrogliosis and pathologic microglial activation; normalizing synaptic protein synthesis, dendritic morphology, and neuronal signaling; and enhancing antioxidant response ${ }^{18-20}$. A phase 2 study in adolescent/adult females with RTT demonstrated excellent safety/tolerability and preliminary evidence of efficacy at $70 \mathrm{mg} / \mathrm{kg}$ twice a day (bid) for 28 days. ${ }^{21}$ Herein, we report a phase 2 study in a larger pediatric cohort, evaluating higher doses and longer treatment duration, and assessing pharmacokinetic-pharmacodynamic (PKPD) correlations to support the dose rationale for future studies.

\section{Methods}

\section{Classification of evidence}

The primary research questions were, (1) Is treatment with trofinetide safe and well-tolerated in the pediatric RTT population? and (2) What is the pharmacokinetic (PK) profile of trofinetide in this population? The secondary question was, (3) Does trofinetide treatment demonstrate improvement of RTT symptoms over placebo? This study provides Class I evidence showing that trofinetide at doses of 50,100 , and $200 \mathrm{mg} / \mathrm{kg}$ bid was well tolerated and generally safe in children/adolescents with RTT, in whom increasing doses were associated with proportional increase in systemic exposure (linear PKs), and at $200 \mathrm{mg} / \mathrm{kg}$ bid demonstrated improvement over placebo across functionally important dimensions of RTT. The study also provides insight into potential efficacy measures for future studies.

\section{Study design}

Study design (dose, length of treatment, and safety and efficacy outcome measures) was informed by the previous adolescent/adult trial (Rett-001). ${ }^{21}$ The present study (hereafter Rett-002) was an exploratory, phase 2, multicenter, double-blind, placebo-controlled, parallel-group trial. The first 62 participants were randomized 1:1:1:1 to placebo or 1 of 3 dose levels of trofinetide: 50,100 , or $200 \mathrm{mg} / \mathrm{kg}$ bid, stratified by age. Following review of blinded safety and tolerability data, the study design was modified to enable enrollment of 20 additional participants randomized $1: 1$ to $200 \mathrm{mg} / \mathrm{kg}$ bid or placebo bid. The aim was to enrich both the high-dose and placebo groups to maximize the likelihood of detecting clinical benefit in this population for whom there are no alternative pharmacotherapies. Total duration of treatment was 56 days, with participants receiving single-blind placebo treatment for 14 days followed by 42 days of double-blind treatment with either drug or placebo. Participants had a posttreatment visit approximately 10 days after the end of treatment. Study design and subject disposition are shown in figure 1 .

\section{Randomization and treatment allocation}

The randomization scheme used 2 age strata (ages 5-10 and 11-15 years) and then assignment to treatment blocks. At the end of the 1-week screening period, the participant was randomized if she met all eligibility criteria, and written informed consent was provided by a legally authorized representative. Randomization was via a web-based randomization system operating 24 hours per day, 7 days per week. Participants were assigned a unique randomization number. Treatment assignments were not disclosed to the sponsor, participants, caregivers, investigators, or research site personnel.

\section{Dosing/dose schedule}

Trofinetide (also known as NNZ-2566) and placebo were administered as a volume-matched strawberry-flavored liquid either orally or via gastrostomy tube. Participants were blindly up-titrated to their assigned dose based on a predefined dosing schedule. The $50 \mathrm{mg} / \mathrm{kg}$ group was up-titrated over 2 days $(8.5 \mathrm{mg} / \mathrm{kg}$ bid, $35 \mathrm{mg} / \mathrm{kg}$ bid, then $50 \mathrm{mg} / \mathrm{kg}$ bid), the 100 $\mathrm{mg} / \mathrm{kg}$ over 3 days $(17.5 \mathrm{mg} / \mathrm{kg}$ bid, $35 \mathrm{mg} / \mathrm{kg}$ bid, $50 \mathrm{mg} / \mathrm{kg}$ bid, then $100 \mathrm{mg} / \mathrm{kg} \mathrm{bid)}$, and the $200 \mathrm{mg} / \mathrm{kg}$ group over 5 days $(17.5 \mathrm{mg} / \mathrm{kg}$ bid, $35 \mathrm{mg} / \mathrm{kg}$ bid, $50 \mathrm{mg} / \mathrm{kg}$ bid, $100 \mathrm{mg} / \mathrm{kg}$ 


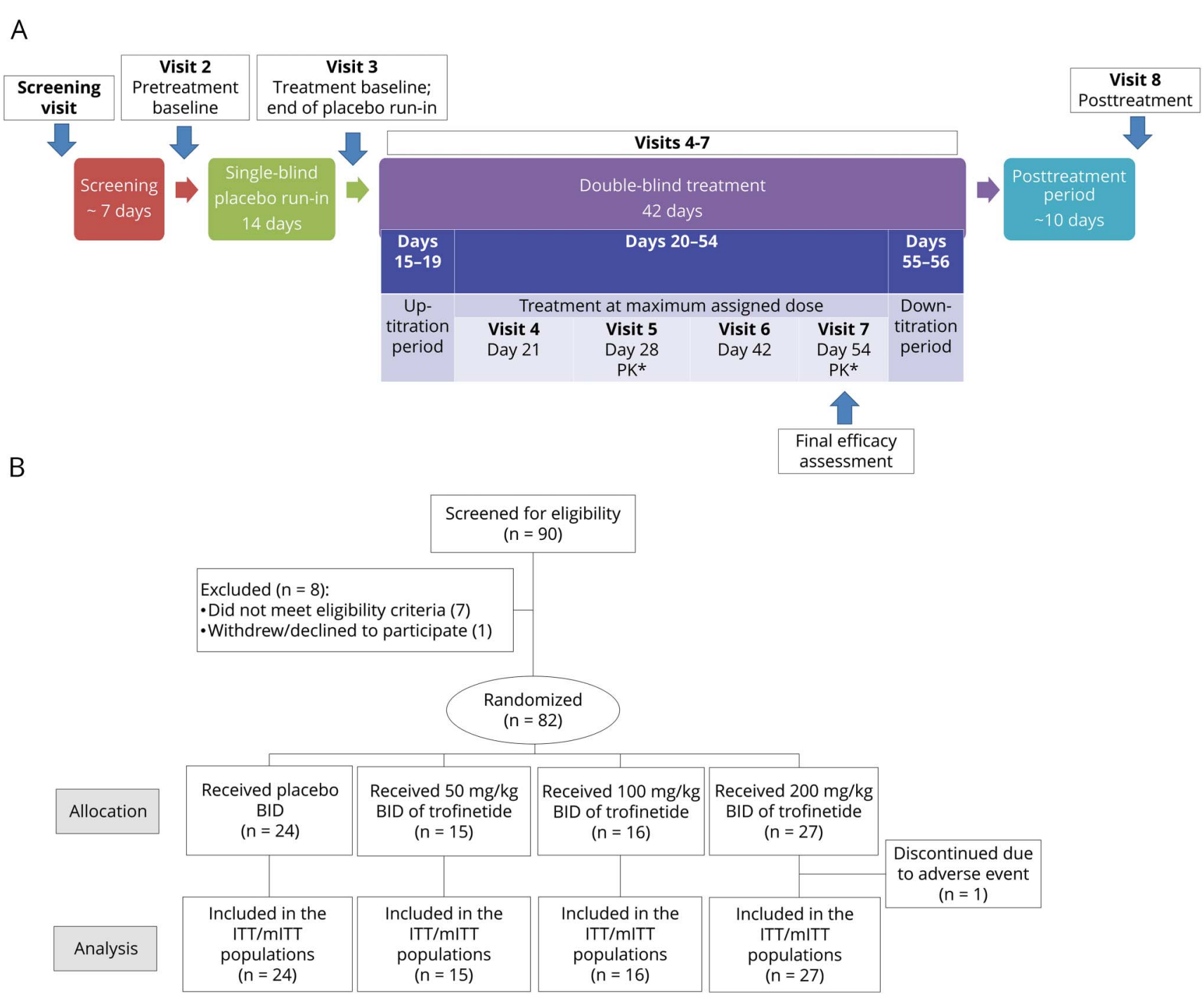

$\mathrm{BID}=$ twice daily dosing; ITT = intention to treat; $\mathrm{mITT}=$ modified intention to treat; $\mathrm{PK}=$ pharmacokinetic.

bid, $150 \mathrm{mg} / \mathrm{kg}$ bid, then $200 \mathrm{mg} / \mathrm{kg}$ bid). The 100 and $200 \mathrm{mg} /$ $\mathrm{kg}$ groups were also down-titrated from their maximum dose after day $54(100 \mathrm{mg} / \mathrm{kg}$ bid on day 55 and $50 \mathrm{mg} / \mathrm{kg}$ bid on day 56$)$. As such, day 54 was the last day when all participants were treated on their maximally assigned dose level.

\section{Participants}

Eighty-two girls between 5 and 15 years of age participated in the study. All participants met the 2010 diagnostic criteria for classic RTT, ${ }^{9}$ had molecular documentation of a pathogenic $M E C P 2$ variant, were in the postregression stage, and were stable on current pharmacologic and behavioral treatments for at least 4 weeks (seizure profile and antiepileptic drugs had to be stable for 8 weeks). Caregivers recorded seizure frequency, medications, and behavioral treatments in a paper diary during the 1-week screening period to confirm stability through the start of the study medication. Data were collected at 12 RTT research centers in the United States.

\section{Standard protocol approvals, registrations, and patient consents}

The study was registered on Clinicaltrials.gov (NCT02715115). Enrollment commenced in March 2016 and the study was completed in January 2017 after target enrollment was reached and participants completed the study. The study was approved at each study site by its institutional review board (IRB) or by the designated centralized IRB for the study. Written informed consent was obtained by the parent or legal guardian for all participants. Oral or written assent was obtained from participants deemed able by the recruiting physician and per local IRB regulations.

\section{Safety assessments}

Safety evaluations included monitoring of adverse events (AEs), clinical laboratory tests (urinalysis, hematology, chemistry [including hemoglobin $\mathrm{A}_{1 \mathrm{c}}$, electrolytes, minerals, protein, lipids, and tests of thyroid, renal, and liver function]), 
vital signs, ECGs, physical examinations, funduscopy and tonsil size, and concomitant medications. Seizures were monitored in the caregiver diary.

\section{PK sampling}

PK samples were collected on day 28 (predose and 2-4 hours post dose) and day 54 (predose, 2-3 hours, and 4-6 hours post dose). Samples of whole blood were collected into $2-\mathrm{mL}$ lithium heparin Vacutainer tubes from a cannula port or via venipuncture and stored until shipment at $-70^{\circ} \mathrm{C}$ (or colder) no more than 2 hours after sample collection. The date and times of collection/storage in the freezer were recorded in a log. The date and time of the most recent dose of study medication and most recent meal relative to that dose were recorded in the caregiver diary. Samples were shipped at designated times on dry ice and using temperature monitoring to the laboratory for storage and analysis. ${ }^{22}$

\section{Efficacy outcome measures}

Efficacy assessments were performed during the treatment and posttreatment visits. Baseline assessments occurred before the first dose of study medication. All clinician raters completed a standardized training and completed regular calibration sessions during the study. Study staff reviewed instructions for completing the caregiver measures with the caregiver rater at each session and reviewed the forms for completeness.

Efficacy measurements were categorized into 4 domains: (1) clinician-completed syndrome-specific measures (RTT Motor Behavioral Assessment [MBA], RTT Domain Specific Concerns-Visual Analog Scale); (2) clinician-completed syndrome-specific global measures (Clinical Global Impression Scales, Improvement and Severity); (3) caregiver-completed syndrome-specific measures (Rett Syndrome Behaviour Questionnaire, Caregiver Top 3 Concerns-Visual Analog Scale, RTT Caregiver Burden Inventory); and (4) physiologic measures (heart and respiratory rate).

For statistical analysis, the end points were further characterized into priority levels of core, secondary, and exploratory. The main efficacy analysis was conducted on core end points, which were identified in the statistical analysis plan prior to unblinding of treatment codes. Core efficacy end points included 5 measures (both clinician- and caregiver-completed) as described below.

\section{Core efficacy end points}

The RTT MBA is a clinician-completed rating scale that has been used as part of the Rett Syndrome Natural History Study. ${ }^{23-25}$ The MBA has 34 items, captured on a 4-point Likert scale, grouped in 3 subscales-Behavior/Social, Orofacial/Respiratory, and Motor/Physical Signs, and a modified scoring rubric used as an outcome variable in Rett-001. ${ }^{21}$

The RTT-Clinician Domain Specific Concerns-Visual Ana$\log$ Scale (RTT-DSC-VAS) is a clinician-completed VAS assessing the severity of concerns in: (1) hand use; (2) ambulation; (3) seizures; (4) autonomic features; (5) behavior; (6) attentiveness; (7) social interaction; and (8) language/communication. Concerns are identified on an individual basis at baseline. Severity is scored at baseline and follow-up visits for each concern by measuring the number of centimeters on a $10-\mathrm{cm}$ VAS line and reported as a percentage of the line. A total VAS score for each participant is calculated as the sum of the scores for the 8 concerns. If a subject had no symptoms/concerns in an area, that domain was not rated, and the score was null for that concern.

The Clinical Global Impression Scale-Improvement (CGI-I) is a clinician-completed assessment of how much the individual's illness has improved/worsened relative to a baseline state, scored using a standardized rubric that is specific to the clinical features of RTT. ${ }^{26}$ A 7-point scale is used: 1 = very much improved; $2=$ much improved; $3=$ minimally improved; $4=$ no change; $5=$ minimally worse; $6=$ much worse; $7=$ very much worse. Day 14 assessments (treatment baseline, end of placebo run-in) were made relative to the pretreatment baseline visit. For all subsequent visits, assessments were made relative to the day-14 visit.

The Rett Syndrome Behaviour Questionnaire (RSBQ) is a validated caregiver-completed rating scale assessing a wide range of neurobehavioral symptoms known to be impaired in RTT. ${ }^{27-31}$ The RSBQ has been correlated with functioning and quality of life and characterized across a range of ages and genetic variations in RTT. ${ }^{13,14,30,32}$ The scale includes 45 items rated on a Likert scale from 0 to 2, 39 of them grouped into 8 subscales (General Mood, Breathing Problems, Hand Behaviors, Repetitive Face Movements, Body Rocking and Expressionless Face, Night-time Behaviors, Fear/Anxiety, and Walking/Standing) whose ratings reflect severity and frequency of symptoms. A total, representing the sum of the 45 items (maximum score 90), and 8 subscale scores are obtained.

The Caregiver Top 3 Concerns VAS is a syndrome-specific measure of 3 signs or symptoms identified by caregivers at baseline on an individual, per-participant basis, as being priority concerns they would like to see improved as a result of treatment. ${ }^{33}$ Caregivers were required to choose 3 concerns from any symptom domain related to the participant's RTT. The severity of each concern is scored using a $10-\mathrm{cm}$ VAS using the aforementioned methodology for the RTT-DSC.

\section{Sample size}

This was an exploratory study with primary outcomes relating to assessment of safety and PK, and secondary outcomes relating to efficacy. The study design with approximately 82 participants enabled randomization of approximately 15 per group to the 50 and $100 \mathrm{mg} / \mathrm{kg}$ groups and approximately 24 per group for the $200 \mathrm{mg} / \mathrm{kg}$ and placebo groups, which was deemed to be sufficient to detect treatment differences.

\section{Statistical analyses}

Safety analyses were conducted for all participants randomized, according to actual treatment received (intention-to- 
treat [ITT] population). AEs and other safety data were summarized as frequencies and percentages by treatment groups. AEs were also summarized by system organ class and preferred term using number and percentages. AEs and serious AEs (SAEs) were listed by severity and by relationship to study treatment. Discontinuations caused by AEs were also listed.

Percent and number of participants with abnormal clinical laboratory or ECG findings were summarized by time point and treatment group. Vital signs, ECG, thyroid, funduscopy, and tonsillar findings were summarized by time point and treatment group. Participants taking concomitant medications were summarized by preferred term and treatment group using numbers and percentages.

An integrated population PK model was developed to describe trofinetide's PK in pediatric patients with RTT using sparse samples. ${ }^{22}$ In addition to clearance, volume of distribution, and absorption rate constant, secondary PK parameters included $\mathrm{T}_{\max }$ (time to maximum concentration), $\mathrm{C}_{\max }$ (maximum concentration), $\mathrm{C}_{\min }$ (trough concentration), $\mathrm{C}_{\mathrm{ss}}$ (steady-state concentration), $t_{1 / 2}$ (terminal elimination half-life), and AUC (area under the concentration vs time curve). Derived PK parameters were used to assess the PKPD correlations between 12-hour exposure $\left(\mathrm{AUC}_{0-12}\right)$ and cumulative exposure over the course of treatment $\left(\mathrm{AUC}_{0-\mathrm{x}}\right)$ and change in core measures. The PK population included participants who received study drug to at least the morning day-28 dose and had a PK sample collection at the specified postdose time point(s).

The efficacy analysis was conducted for the modified ITT (mITT) population, which included all participants randomized to receive at least one dose of double-blind study medication, and differences between each active treatment group and the placebo group were assessed. Comparisons of mean change on each core efficacy measure were assessed from treatment baseline (day 14, end of placebo run-in) to day 54 (end of treatment assessment, the last visit before down-titration). For the CGI-I, actual values at the end of treatment were compared as there are no baseline values for CGI-I.

Analyses were performed for each core end point using a generalized linear model. Treatment baseline and placebo response (change from pretreatment baseline to treatment baseline or observed value at treatment baseline for CGI-I) were included as covariates in the model, but dropped from the final model if not significant at the $p \leq 0.1$ two-sided level. Effect sizes were determined using Cohen $d$. For efficacy analyses of the mITT population, missing data were imputed with the median value for the participant's assigned dose group at that visit. The imputation was performed for individual instrument items; any subscale subtotals and totals for a given instrument were calculated based on the imputed individual items. No multiplicity adjustments were performed. If normality and homogeneity of variance assumptions were substantially violated, an appropriate nonparametric test would be performed instead. Conclusions about the study's overall evidence of clinical improvement were based on the totality of efficacy data for the prespecified core end points rather than for a single primary end point.

\section{Data availability}

The data reported are part of an ongoing sponsor-led clinical development program. As such, complete datasets for the study will not be made available with the report.

\section{Results}

\section{Demographics}

A total of 82 participants from 12 study sites were randomized in this study: 24 in the placebo bid group, 15 in the $50 \mathrm{mg} / \mathrm{kg}$ bid trofinetide group, 16 in $100 \mathrm{mg} / \mathrm{kg}$ bid trofinetide group, and 27 in the $200 \mathrm{mg} / \mathrm{kg}$ bid trofinetide group. All 82 participants were included in the ITT population (safety analysis) and in the mITT population (efficacy analysis). The PK population included all 58 participants who received treatment with trofinetide. The mean age of the cohort was 9.7 years (range 5.1-15.9 years), 94\% were white, and mean weight was $26.1 \mathrm{~kg}$. Overall demographic characteristics for participants were balanced across the treatment groups; information for the mITT population is shown in table 1 .

\section{Safety}

Safety and tolerability of trofinetide was very good at all 3 dose levels. No deaths occurred in the study. Only one participant ( $200 \mathrm{mg} / \mathrm{kg}$ bid group) was withdrawn from the study at the request of her parents because of increased mild gastroesophageal reflux, moderate diarrhea, and mild vomiting, which resolved uneventfully after discontinuation. Four SAEs occurred in 3 participants: 1 participant receiving placebo, 1 participant receiving $100 \mathrm{mg} / \mathrm{kg}$ bid, and 1 participant receiving $200 \mathrm{mg} / \mathrm{kg}$ bid. All the SAEs were deemed not related to study medication and resolved by the end of the study.

A summary of AEs during the double-blind treatment period occurring in at least 2 participants is shown in table 2 . The most common AEs reported during the double-blind period across all treatment groups were diarrhea (27\%), vomiting (15\%), upper respiratory tract infection (12\%), and pyrexia (10\%). Diarrhea was reported in $27 \%$ in the $50 \mathrm{mg} / \mathrm{kg}$ bid group, $13 \%$ for the $100 \mathrm{mg} / \mathrm{kg}$ bid group, and $56 \%$ in the $200 \mathrm{mg} / \mathrm{kg}$ bid group. Most AEs were mild or moderate in intensity and most events were considered not related to study drug.

No systematic evidence of withdrawal effects was observed when the study drug was discontinued. Clinical laboratory tests, ECGs, vital signs, and physical examinations (including funduscopy and tonsil size) indicated no time- or dosedependent patterns.

\section{Efficacy}

Trofinetide demonstrated statistically significant evidence of clinical improvement $(p<0.05)$ for the $200 \mathrm{mg} / \mathrm{kg}$ bid dose over placebo in 3 core measures: RSBQ (total score, core 
Table 1 Baseline demographics by treatment group (modified intention to treat)

\begin{tabular}{|c|c|c|c|c|c|}
\hline & $\begin{array}{l}\text { Placebo } \\
(n=24)\end{array}$ & $\begin{array}{l}50 \mathrm{mg} / \mathrm{kg} \\
(\mathrm{n}=15)\end{array}$ & $\begin{array}{l}100 \mathrm{mg} / \mathrm{kg} \\
(\mathrm{n}=16)\end{array}$ & $\begin{array}{l}200 \mathrm{mg} / \mathrm{kg} \\
(\mathrm{n}=27)\end{array}$ & $\begin{array}{l}\text { All participants } \\
(\mathrm{n}=82)\end{array}$ \\
\hline \multicolumn{6}{|l|}{ Age, y } \\
\hline Mean (SD) & $9.38(3.26)$ & $10.06(3.18)$ & $10.81(3.10)$ & $9.23(3.88)$ & $9.73(3.43)$ \\
\hline Median & 9.64 & 9.54 & 9.66 & 7.49 & 9.41 \\
\hline \multicolumn{6}{|l|}{ Height, $^{a} \mathrm{~cm}$} \\
\hline Mean (SD) & $122.69(12.67)$ & $124.12(11.70)$ & 129.55 (12.76) & $121.55(15.19)$ & $123.86(13.50)$ \\
\hline Median & 119.70 & 122.10 & 130.30 & 117.00 & 120.90 \\
\hline \multicolumn{6}{|l|}{ Weight, kg } \\
\hline Mean (SD) & $24.20(6.87)$ & $26.13(9.78)$ & $30.43(12.16)$ & $25.22(11.51)$ & $26.10(10.24)$ \\
\hline Median & 23.75 & 22.60 & 28.65 & 21.30 & 23.05 \\
\hline \multicolumn{6}{|l|}{$\mathrm{BMI}^{\mathrm{a}} \mathrm{kg} / \mathrm{cm}^{2}$} \\
\hline Mean (SD) & $16.00(2.85)$ & $16.50(3.61)$ & $17.70(5.06)$ & $16.31(3.57)$ & $16.52(3.70)$ \\
\hline Median & 15.97 & 15.04 & 16.96 & 15.70 & 15.81 \\
\hline \multicolumn{6}{|l|}{ Age category, n (\%) } \\
\hline$\leq 10 y$ & $15(63)$ & $10(67)$ & $10(63)$ & $17(63)$ & $52(63)$ \\
\hline$>10 y$ & $9(38)$ & $5(33)$ & $6(38)$ & $10(37)$ & $30(37)$ \\
\hline \multicolumn{6}{|l|}{ Ethnicity, n (\%) } \\
\hline Hispanic & $0(0)$ & $1(7)$ & $1(6)$ & $6(22)$ & $8(10)$ \\
\hline Not Hispanic & $24(100)$ & $14(93)$ & $14(88)$ & $21(78)$ & $73(89)$ \\
\hline Not reported & $0(0)$ & $0(0)$ & $1(6)$ & $0(0)$ & $1(1)$ \\
\hline \multicolumn{6}{|l|}{ Race, n (\%) } \\
\hline American Indian or Alaskan Native & $0(0)$ & $0(0)$ & $0(0)$ & $0(0)$ & $0(0)$ \\
\hline Asian & $1(4)$ & $0(0)$ & $0(0)$ & $2(7)$ & $3(4)$ \\
\hline Black or African American & $0(0)$ & $0(0)$ & $1(6)$ & $0(0)$ & $1(1)$ \\
\hline Native Hawaiian or other Pacific Islander & $0(0)$ & $0(0)$ & $0(0)$ & $0(0)$ & $0(0)$ \\
\hline White & $22(92)$ & $15(100)$ & $15(94)$ & $25(93)$ & $77(94)$ \\
\hline Other & $1(4)$ & $0(0)$ & $0(0)$ & $0(0)$ & $1(1)$ \\
\hline
\end{tabular}

Abbreviation: $\mathrm{BMI}=$ body mass index.

a For height and BMI for the placebo group, $\mathrm{n}=23$.

neurobehavioral RTT symptoms, $p=0.042$ ), CGI-I (overall clinical status, $p=0.029$ ), and RTT-DSC (most concerning aspects of RTT identified by clinicians, $p=0.025$ ). Results for the 5 core efficacy measures across the treatment groups are shown in table 3.

Among the 3 outcome measures with $p<0.05$, the magnitude of effect (\% change of the median score) for RTT-DSC was $15 \%$ (vs 5\% for placebo) and the magnitude of effect (\% change of the mean score) for RSBQ was 16\% (vs 6\% for placebo). For CGI-I, the mean was 3.0 for the $200 \mathrm{mg} / \mathrm{kg}$ bid group and was 3.5 for placebo, with more than $20 \%$ of participants scoring a 2 , "much improved," compared with less than $5 \%$ of those on placebo.
Cohen $d$ effect sizes were -0.645 for CGI-I, -0.247 for the RTTDSC, and -0.487 for the RSBQ total.

\section{Pharmacokinetics and pharmacodynamics}

Trofinetide showed linear PKs across the dose range tested. These results are consistent with previous data in adult and adolescent patients (Rett-001). From a drug metabolism perspective, no accumulation, metabolic inhibition, or induction was observed during treatment. Geometric mean estimates for the predicted area under the concentration vs time curve $\left(\right.$ AUC $_{0-12}, \mu \mathrm{g} / \mathrm{mL} \cdot \mathrm{h}$ ) were 136.5 (50 mg/kg bid), 321.2 (100 $\mathrm{mg} / \mathrm{kg} \mathrm{bid})$, and $530.6(200 \mathrm{mg} / \mathrm{kg}$ bid $)$. Geometric mean estimates of peak concentration $\left(\mathrm{C}_{\max ,}, \mu \mathrm{g} / \mathrm{mL}\right)$ were $18.7(50$ 
Table 2 Incidence of treatment-emergent adverse events during the double-blind period (days 15-56, intention-to-treat population)

\begin{tabular}{|c|c|c|c|c|c|}
\hline System organ class preferred term ${ }^{a}$ & $\begin{array}{l}\text { Placebo } \\
(n=24)\end{array}$ & $\begin{array}{l}50 \mathrm{mg} / \mathrm{kg} \\
(\mathrm{n}=15)\end{array}$ & $\begin{array}{l}100 \mathrm{mg} / \mathrm{kg} \\
(\mathrm{n}=16)\end{array}$ & $\begin{array}{l}200 \mathrm{mg} / \mathrm{kg} \\
(\mathrm{n}=27)\end{array}$ & $\begin{array}{l}\text { Total } \\
(n=82)\end{array}$ \\
\hline Reported at least 1 event & $14(58)$ & $8(53)$ & $11(69)$ & $19(70)$ & $52(63)$ \\
\hline \multicolumn{6}{|l|}{ Gastrointestinal disorders } \\
\hline Diarrhea & $1(4)$ & $4(27)$ & $2(13)$ & $15(56)$ & $22(27)$ \\
\hline Vomiting & $3(13)$ & $1(7)$ & $2(13)$ & $6(22)$ & $12(15)$ \\
\hline Constipation & $0(0)$ & $0(0)$ & $0(0)$ & $2(7)$ & $2(2)$ \\
\hline \multicolumn{6}{|c|}{ General disorders and administration-site conditions } \\
\hline Pyrexia & $2(8)$ & $0(0)$ & $3(19)$ & $3(11)$ & $8(10)$ \\
\hline \multicolumn{6}{|l|}{ Infections and infestations } \\
\hline Upper respiratory tract infection & $3(13)$ & $1(7)$ & $0(0)$ & $5(19)$ & $9(11)$ \\
\hline Nasopharyngitis & $2(8)$ & $1(7)$ & $0(0)$ & $1(4)$ & $4(5)$ \\
\hline Ear infection & $2(8)$ & $0(0)$ & $0(0)$ & $1(4)$ & $3(4)$ \\
\hline Gastroenteritis & $0(0)$ & $0(0)$ & $1(6)$ & $1(4)$ & $2(2)$ \\
\hline Pneumonia & $1(4)$ & $0(0)$ & $0(0)$ & $1(4)$ & $2(2)$ \\
\hline \multicolumn{6}{|l|}{ Metabolism and nutrition disorders } \\
\hline Decreased appetite & $1(4)$ & $1(7)$ & $0(0)$ & $0(0)$ & $2(2)$ \\
\hline \multicolumn{6}{|l|}{ Nervous system disorders } \\
\hline Somnolence & $1(4)$ & $1(7)$ & $0(0)$ & $0(0)$ & $2(2)$ \\
\hline Seizure & $1(4)$ & $0(0)$ & $0(0)$ & $0(0)$ & $1(1)$ \\
\hline Seizure cluster & $0(0)$ & $0(0)$ & $0(0)$ & $1(4)$ & $1(1)$ \\
\hline Tonic convulsion & $0(0)$ & $0(0)$ & $1(6)$ & $0(0)$ & $1(1)$ \\
\hline \multicolumn{6}{|l|}{ Psychiatric disorders } \\
\hline Irritability & $0(0)$ & $0(0)$ & $1(6)$ & $1(4)$ & $2(2)$ \\
\hline \multicolumn{6}{|c|}{ Respiratory, thoracic, and mediastinal disorders } \\
\hline Cough & $2(8)$ & $0(0)$ & $1(6)$ & $1(4)$ & $4(5)$ \\
\hline Sinus congestion & $0(0)$ & $0(0)$ & $1(6)$ & $2(7)$ & $3(4)$ \\
\hline Rhinorrhea & $1(4)$ & $1(7)$ & $0(0)$ & $0(0)$ & $2(2)$ \\
\hline \multicolumn{6}{|l|}{ Skin and subcutaneous tissue disorders } \\
\hline Dermatitis diaper & $0(0)$ & $1(7)$ & $0(0)$ & $1(4)$ & $2(2)$ \\
\hline Rash maculopapular & $1(4)$ & $0(0)$ & $0(0)$ & $1(4)$ & $2(2)$ \\
\hline
\end{tabular}

Data represent $\mathrm{n}(\%)$ of participants.

${ }^{\text {a }}$ Events occurring in at least 2 participants. Seizure adverse events are an adverse event of interest in this population, so all seizure-related adverse events are listed.

$\mathrm{mg} / \mathrm{kg}$ bid), 48.7 (100 mg/kg bid), and 83.7 (200 mg/kg bid). The geometric mean of the apparent terminal elimination half-life $\left(\mathrm{T}_{1 / 2}\right)$ varied from 5.3 to 6.1 hours across the 3 dosing groups.

As observed previously in adults and adolescent patients, body weight had a significant effect on clearance and volume of distribution and consequently on overall systemic exposure to trofinetide. Participants with lower body weight had lower overall systemic exposure to trofinetide, despite the use of a dosing regimen based on body weight (i.e., $\mathrm{mg} / \mathrm{kg}$ ). Differences in bioavailability were also observed between morning and evening doses, which may be explained by different factors, including circadian variation in absorption or metabolism or eventually food effect, ${ }^{22}$ which also appears to occur in preclinical studies (unpublished data, BioAnalytical Systems, Inc, 2011). 
Table 3 Change from treatment baseline (day 14) to end of treatment (day 54) in core efficacy outcomes (modified intention to treat)

\begin{tabular}{|c|c|c|c|c|c|}
\hline Outcome measure & $\begin{array}{l}\text { Prespecified } \\
\text { covariates, } p \leq 0.1^{a}\end{array}$ & $\begin{array}{l}\text { Placebo } \\
(n=24)\end{array}$ & $\begin{array}{l}50 \mathrm{mg} / \mathrm{kg} \\
(\mathrm{n}=15)\end{array}$ & $\begin{array}{l}100 \mathrm{mg} / \mathrm{kg} \\
(\mathrm{n}=16)\end{array}$ & $\begin{array}{l}200 \mathrm{mg} / \mathrm{kg} \\
(\mathrm{n}=27)\end{array}$ \\
\hline \multicolumn{6}{|l|}{ RSBQ total } \\
\hline Treatment baseline, mean (SD) & & $39.5(11.83)$ & $44.7(13.57)$ & $40.3(11.26)$ & $42.2(10.99)$ \\
\hline Change D14-D54, LSmean (SE) & PR & $-2.3(1.54)$ & $-3.0(1.95)$ & $-1.5(1.96)$ & $-6.7(1.46)$ \\
\hline$p$ Value vs placebo & & NA & 0.768 & 0.749 & 0.042 \\
\hline
\end{tabular}

\section{RTT-DSC total}

\begin{tabular}{|c|c|c|c|c|c|}
\hline \multicolumn{6}{|l|}{ Exact median test ${ }^{b}$} \\
\hline Treatment baseline, median & & 473.3 & 450.0 & 445.35 & 516.6 \\
\hline Change D14-D54, median & UnAdj & -25.85 & -32.50 & -12.10 & -76.00 \\
\hline$p$ Value vs placebo & & NA & 0.999 & 0.748 & 0.025 \\
\hline \multicolumn{6}{|l|}{ CGI-I } \\
\hline Treatment baseline & & $-^{c}$ & $-^{c}$ & $-^{c}$ & $-^{c}$ \\
\hline Change D14-D54, LSmean (SE) & UnAdj & $3.5(0.14)$ & $3.3(0.17)$ & $3.4(0.17)$ & $3.0(0.13)$ \\
\hline$p$ Value vs placebo & & NA & 0.391 & 0.703 & 0.029 \\
\hline \multicolumn{6}{|l|}{ Top 3 caregiver concerns } \\
\hline Treatment baseline, mean (SD) & & $223.87(54.51)$ & 237.69 (63.97) & $211.55(42.60)$ & $245.90(49.12)$ \\
\hline Change D14-D54, LSmean (SE) & UnAdj & $-12.52(8.78)$ & $-16.56(11.10)$ & $-2.09(10.75)$ & $-18.54(8.28)$ \\
\hline$p$ Value vs placebo & & NA & 0.776 & 0.455 & 0.619 \\
\hline \multicolumn{6}{|l|}{ MBA total } \\
\hline Treatment baseline, mean (SD) & & $48.8(7.99)$ & $46.6(8.77)$ & $48.6(8.82)$ & $46.6(13.10)$ \\
\hline Change D14-D54, LSmean (SE) & $\mathrm{TBL}, \mathrm{PR}$ & $-2.6(0.99)$ & $-2.8(1.25)$ & $-2.4(1.23)$ & $-2.9(0.94)$ \\
\hline$p$ Value vs placebo & & NA & 0.872 & 0.925 & 0.840 \\
\hline
\end{tabular}

Abbreviations: CGI-I = Clinical Global Impression Scale-Improvement; D = day; LSmean = least-squares mean; MBA = Motor Behavioral Assessment; NA = not applicable; PR = placebo response; RSBQ = Rett Syndrome Behaviour Questionnaire; RTT-DSC = Rett syndrome-Clinician Domain Specific Concerns; TBL = treatment baseline; UnAdj = unadjusted.

a Prespecified model covariates if $p \leq 0.1$ : TBL and/or PR. UnAdj is noted if neither covariate was included in the final model. No multiplicity adjustments were performed.

${ }^{b}$ The distribution of data in the RTT-DSC was nonnormal. Consequently, group medians were used in the analysis of this end point and statistical significance was determined by the exact median test.

' $\mathrm{CGI}-\mathrm{I}$ has no pretreatment baseline value. The CGI-I values at day 14 are ratings of change from day 0 (the pre-treatment baseline) to day 14 (end of placebo run-in). CGI-I assessments done after day 14 are referenced to participant's status at day 14. Mean of actual scores was assessed at day 54 (end of treatment).

At the end of the dosing period, data indicate that clinical benefit was continuing to accrue, as the difference between the placebo and $200 \mathrm{mg} / \mathrm{kg}$ bid groups appeared to continue to increase (figure 2). Furthermore, there is evidence of a diminution of effect following cessation of dosing. Moreover, as shown in figure 3 , an exploratory PKPD analysis suggests a correlation between trofinetide exposure (expressed as $\mathrm{AUC}_{0-12}$ [dosing interval] and cumulative AUC [over 42 days]) and the magnitude of response on RSBQ, RTT-DSC, and CGI-I.

\section{Additional prespecified analyses}

Across the core efficacy measures, improvement was seen in clinically important symptom areas core to RTT: breathing problems, repetitive movements (including hand function), mood dysfunction (including nighttime behaviors), ambulation, and seizures. On the RSBQ based on comparison with placebo and Cohen $d$ effect sizes (figure 4A), all of the subscales except one were directionally in favor of the $200 \mathrm{mg} / \mathrm{kg}$ bid treatment group with notable improvement in mood dysfunction and disruptive behavior (General Mood subscale, $p=0.007$ ), breathing problems (Breathing subscale $p=0.095$ ), and repetitive movements (Repetitive Face Movement subscale, $p=$ $0.047)$.

On RTT-DSC, improvements were notable in 2 domains, ambulation $(p=0.040)$ and seizures $(p=0.057)$, but were also observed to be directionally in favor of $200 \mathrm{mg} / \mathrm{kg}$ bid treatment for attentiveness and social interaction based on Cohen $d$ effect sizes (figure 4B). 


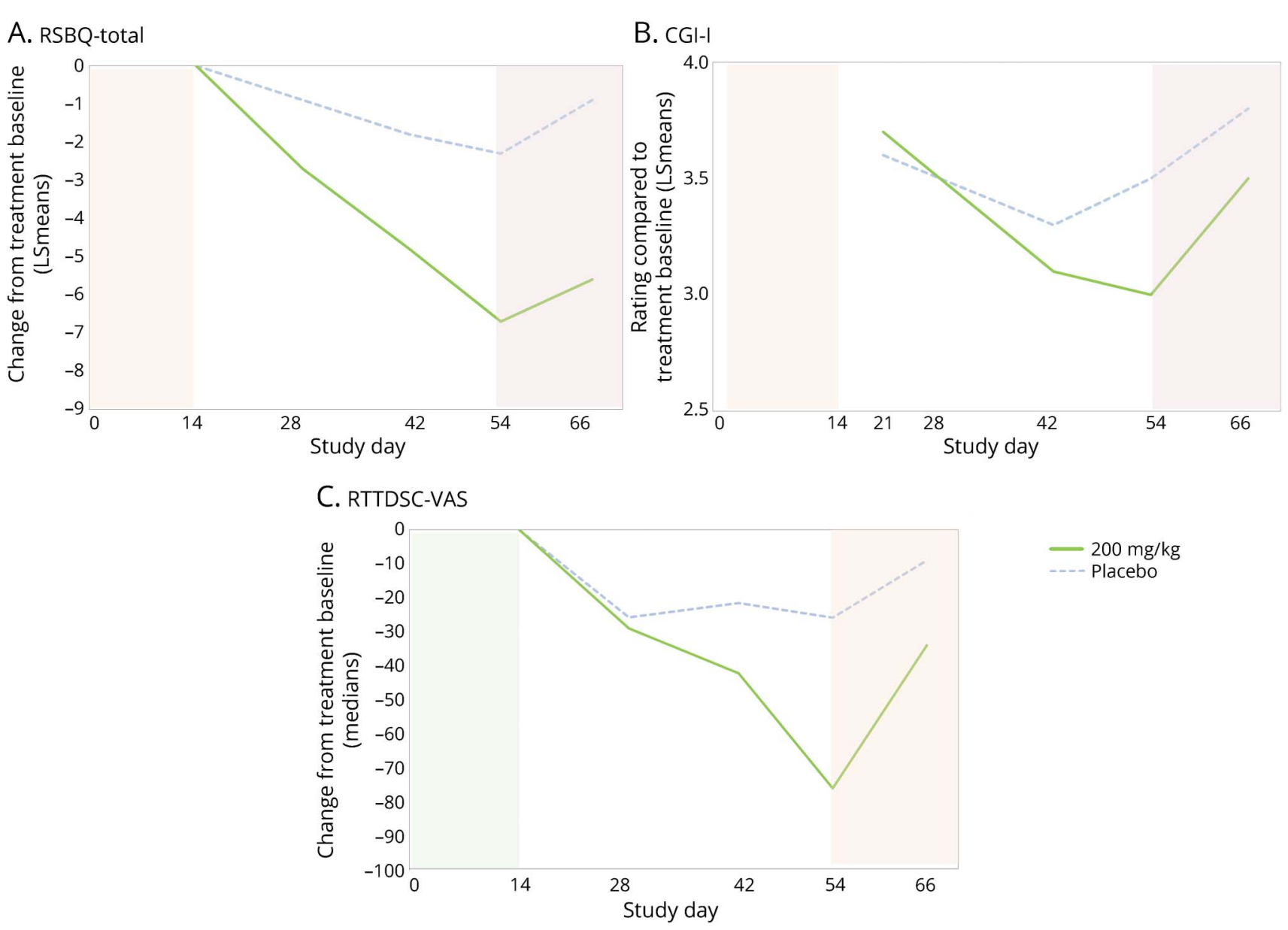

(A) Change from treatment baseline of the $200 \mathrm{mg} / \mathrm{kg}$ group compared to placebo in the mITT population for the RSBQ total score. EOT measured at day 54 . Posttreatment follow-up at day 66. Improvement is a decrease in score. LSmeans: placebo response included as covariate in the model. (B) Absolute values of the $200 \mathrm{mg} / \mathrm{kg}$ group compared to placebo in the mITT population for the CGI-I. EOT measured at day 54. Posttreatment follow-up at day 66. Improvement is lower score. LSmeans. (C) Change from treatment baseline of the $200 \mathrm{mg} / \mathrm{kg}$ group compared to placebo in the mITT population for the RTT-DSC. EOT measured at day 54. Posttreatment follow-up at day 66. Improvement is a decrease in score. Exact median test. Treatment baseline $=$ day 14 . CGI-I = Clinical Global Impression Scale-Improvement; EOT = end of treatment; LSmean = least-squares mean; mITT = modified intention to treat; RSBQ = Rett Syndrome Behaviour Questionnaire; RTT-DSC = Rett syndrome-Clinician Domain Specific Concerns; VAS = Visual Analog Scale.

On RTT-DSC, concerns are identified on an individual, perparticipant basis. The types of symptoms that improved for ambulation included being able to walk unassisted or improving on a certain motor milestone (e.g., walking a certain distance, walking on stairs, improved stability). For seizures, concerns included both frequency and severity but symptoms that improved appear to be primarily the frequency of seizures.

\section{Discussion}

This pediatric phase 2 study confirmed previous findings and expanded the safety, tolerability, and efficacy profile observed in the initial adolescent/adult phase 2 trofinetide trial in RTT. ${ }^{21}$ All dose levels of trofinetide were generally safe and well-tolerated in individuals with RTT aged 5 to 15 years. No sentinel safety events occurred. Few SAEs and only one discontinuation because of AEs occurred, and no overt time-dependent issues related to tolerability were noted. Diarrhea occurred more frequently in the active treatment groups but did not affect overall tolerability. It is important to note that chronic constipation and corresponding pharmacologic treatment are highly prevalent in RTT, which may be a confounding factor. Objective assessments (e.g., laboratory assessments, vital signs) did not reveal any systematic pattern of clinical detriment.

Efficacy measures indicate clinically relevant improvements in a range of core symptoms of RTT at the highest dose of $200 \mathrm{mg} / \mathrm{kg}$ bid as shown by statistically significant improvement in 3 of the 5 core efficacy end points. The magnitude of this positive response was at a clinically meaningful level, as evidenced by the effect size of the differences in the RSBQ and RTT-DSC total and subscale scores and a face validity assessment of the range of symptoms. The findings on the 2 rating scales are supported by improvements on overall functioning as 
A. RSBQ - total
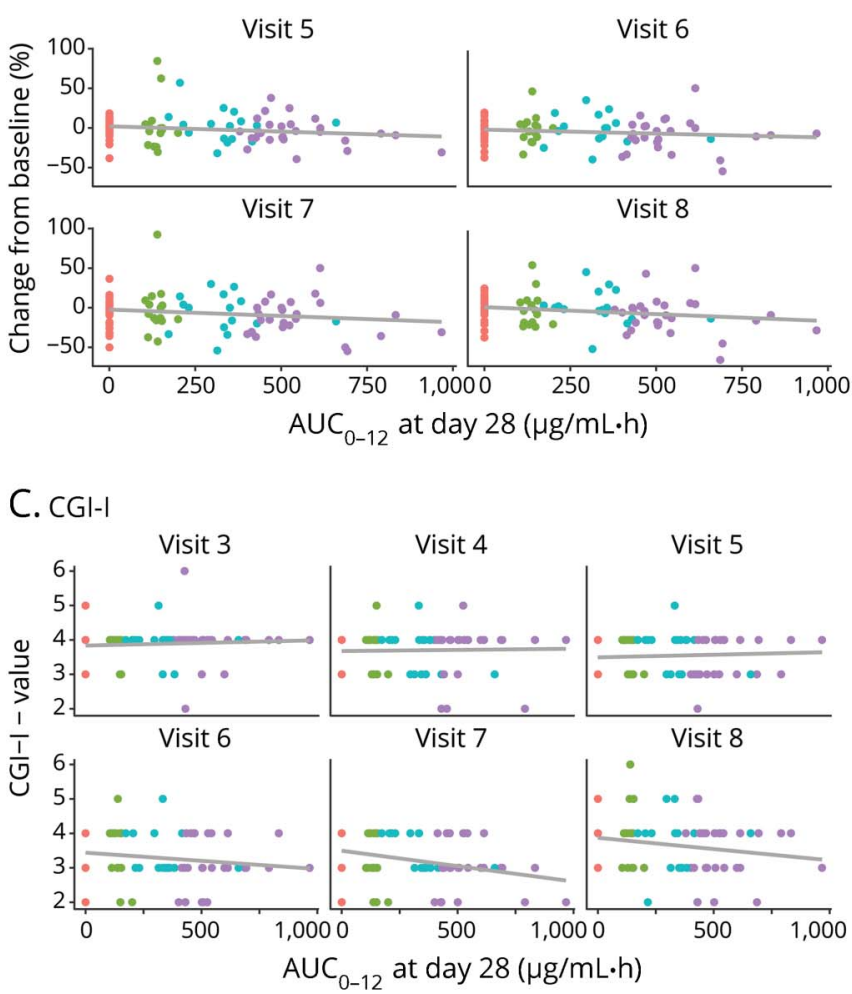

E. RTT-DSC-total score

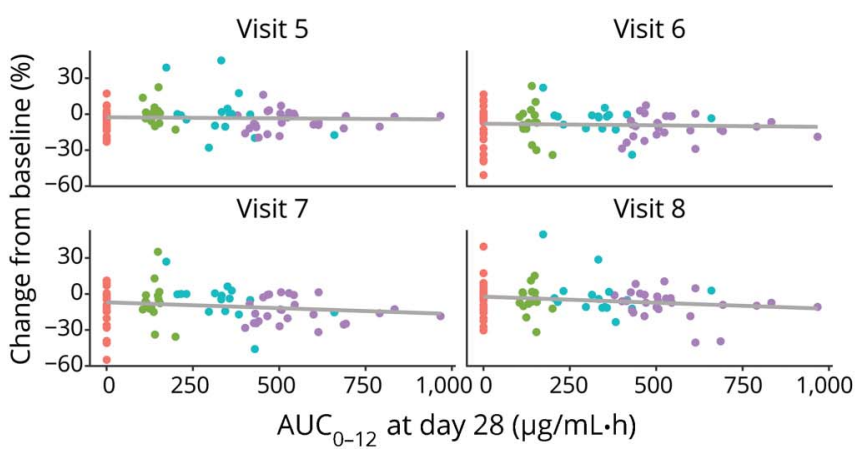

- Placebo

- $50 \mathrm{mg} / \mathrm{kg}$

- $100 \mathrm{mg} / \mathrm{kg}$

- $200 \mathrm{mg} / \mathrm{kg}$

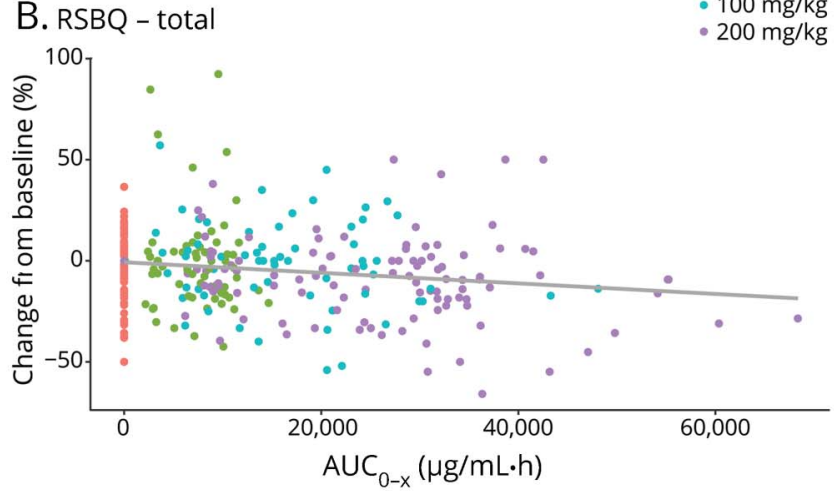

D. CGI-I

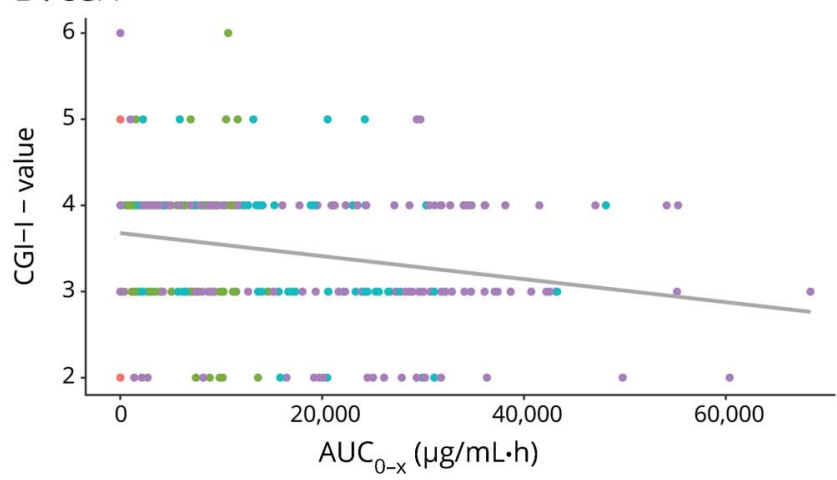

F. RTT-DSC-total score

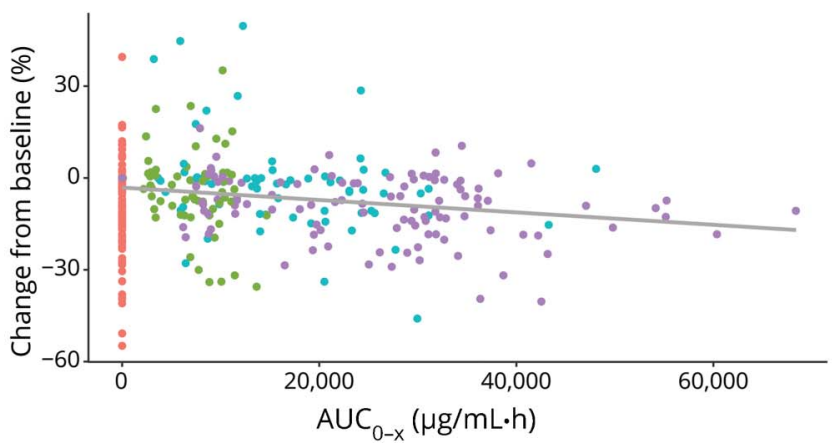

Relationship between change from treatment baseline in RBSQ, CGI-I, and RTT-DSC and AUC $0-12$ at different visits and over the active treatment period. (A) Relationship between percentage change from treatment baseline in RSBQ-total score and AUC $\mathrm{C}_{0-12}$ at day 28. (B) Relationship between percentage change from treatment baseline in RSBQ-total score and cumulative AUC during the active dosing period. (C) Relationship between CGI-I scores and AUC $0-12$ at day 28. (D) Relationship between CGI-I score and cumulative AUC during the active dosing period. (E) Relationship between percentage change from treatment baseline in RTT-DSC score and AUC $_{0-12}$ at day 28. (F) Relationship between percentage change from treatment baseline in RTT-DSC SCore and cumulative AUC during the active dosing period. Visit 3 (day 14, end of placebo run-in), visit 4 (day 21), visit 5 (day 28), visit 6 (day 42 ), visit 7 (day 54 , end of treatment), visit 8 (day 66 , posttreatment). Solid lines are obtained by linear regression. Where applicable, placebo data $(A \cup C=0)$ from different visits are pooled together. AUC $=$ area under the concentration vs time curve; CGI-I = Clinical Global Impression Scale-Improvement; RSBQ = Rett Syndrome Behaviour Questionnaire; RTTDSC = Rett syndrome-Clinician Domain Specific Concerns.

measured by the CGI-I. Both the CGI-I and RSBQ total had medium effect sizes, and 4 of the RSBQ subscales and 2 of the RTT-DSC subscales showed Cohen $d$ effect sizes $\geq 0.3$ (small to medium). Effect sizes of this range are reported in trials of other CNS disorders using behavioralbased rating scales and are comparable to those reported for Food and Drug Administration-approved treatments for other disorders, such as major depressive disorder (mean 0.3 , range $0.17-0.42)^{34}$

Of note, the RSBQ and RTT-DSC data suggest improvements across a range of symptom domains and individual symptoms, which included repetitive behaviors, breathing problems, mood abnormalities/disruptive behavior, ambulation 


\section{A. RSBQ subscales (200mg/kg vs placebo)}

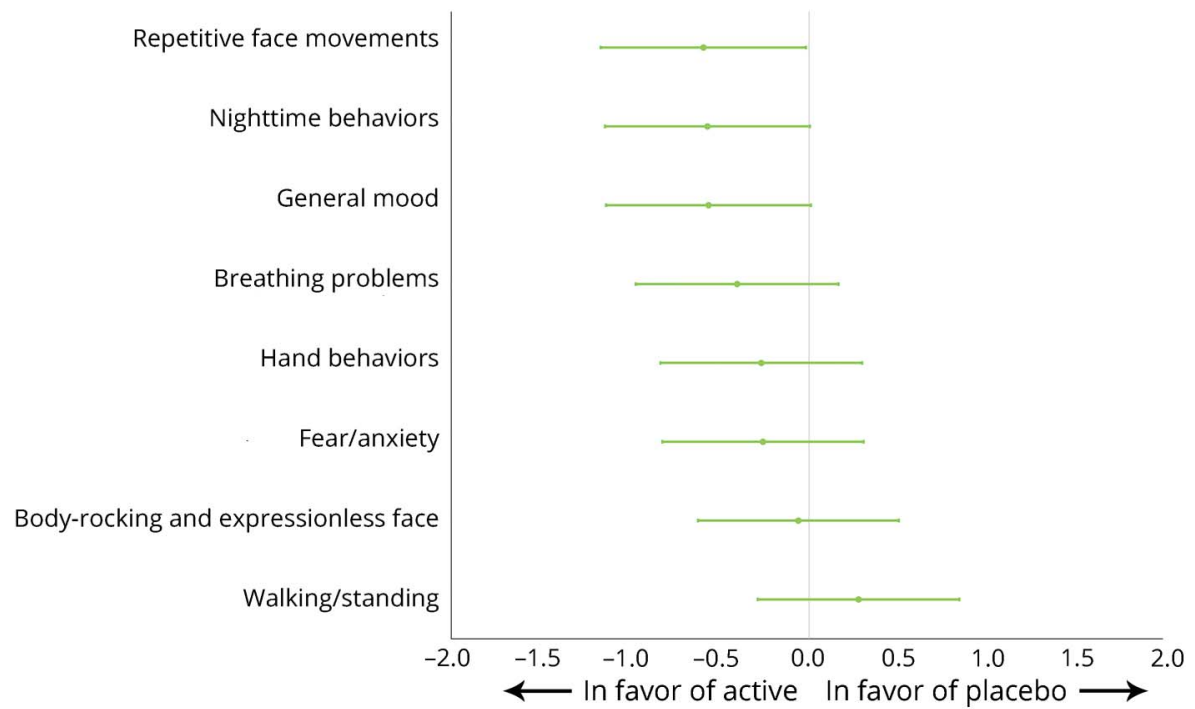

B. RTT-DSC domains $(200 \mathrm{mg} / \mathrm{kg}$ vs placebo)

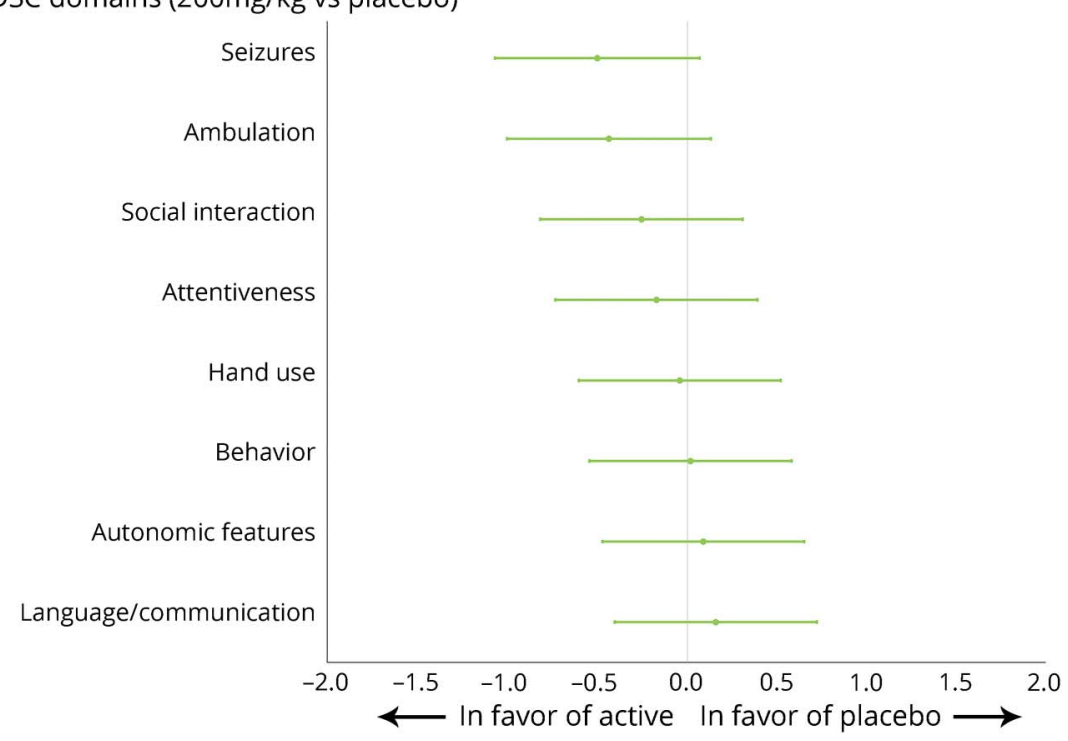

Cohen $d$ effect sizes for the RSBQ (A) and RTTDSC-VAS (B). Cohen $d$ values are unadjusted that is, do not incorporate covariate information from treatment baseline or placebo response. bid = twice $a$ day; RSBQ = Rett Syndrome Behaviour Questionnaire; RTTDSC = Rett syndrome-Clinician Domain Specific Concerns; VAS = Visual Analog Scale. impairment, and seizures. This multiple-domain effect is consistent with the adolescent/adult Rett-001 trial, ${ }^{21}$ which showed improvement in measures covering a wide range of manifestations of the disease (e.g., MBA, CGI-I), and consistent with the generalized mechanisms of action of trofinetide. $^{17,35}$ As in the present study, in Rett-001 apparent clinical benefits were also exhibited in both clinician and caregiver assessments and in a number of core RTT symptoms. ${ }^{21}$ In addition, as in the present study, the clinical improvement was still increasing at the end of treatment and declined after cessation of treatment. The relative consistency of effects (albeit captured by a partially different set of measures and in an older population with shorter exposure to trofinetide) gives additional confidence that the results of the previous study were not simply attributable to chance.
There are no validated biomarkers available to assess druginduced physiologic, cognitive, and behavioral effects, which can ultimately be linked to clinical improvement and efficacy. Such a limitation may be partly overcome by the evaluation of exposure-response relationships. ${ }^{36,37}$ In this pediatric study, despite the variability of the relatively small cohort, a correlation was found between drug exposure and magnitude of changes in response to treatment. While an integrated analysis of all available data needs to be performed (including an evaluation of the response over a longer treatment period to establish the dose-exposure-response relationship), the efficacy data from this study suggest that the group separation during the dosing period was due to beneficial treatment effect and not to other differences between the 2 arms that occurred simply by chance. Taken together with the observation of sustained improvement at the end of treatment, and 
the diminution of effect post treatment, these observations also suggest that clinical benefit is likely to increase further with a longer treatment period than was studied in this trial. Overall, the observed clinical improvement in the present pediatric trial was more manifest than in the previous trial, with younger age (i.e., greater neuroplasticity), higher doses (i.e., higher drug exposure), and longer drug treatment duration (i.e., 28 days in Rett-001 vs 42 days in Rett-002) as potential contributors.

The PK findings replicate findings from the adult trial showing that weight is an influential moderator of systemic exposure, a feature that is common to many drugs used in children. ${ }^{38,39}$ While $\mathrm{mg} / \mathrm{kg}$ dosing was used, dose levels were not banded by weight in this protocol, as such systemic exposure was not comparable across all participants receiving a given dose of trofinetide. Consequently, dose per se was not as important as drug exposure as a determinant factor for the magnitude of the response to trofinetide. In addition, as exposure will vary not only with the dose, but also with body weight, identifying dosing regimens that provide optimal exposure will likely reduce variability in response. Therefore, weight-banded dosing or similar algorithms should be considered in future trials to adjust dosing in this population. 39,40

For this phase 2 study in a pediatric population, the RSBQ was added to the assessment battery. The RSBQ is the most widely used behavioral instrument in RTT, in part because of its disorder-specificity and its reliability and validity in particular for the RTT pediatric population. ${ }^{12-14,32}$ More recently, the RSBQ has also shown sensitivity to interventions and correlations with functioning and quality of life in RTT. ${ }^{14,28,31}$ The RSBQ could more properly be labeled as a "neurobehavioral" measure since it includes RTT features that are modulated rather than triggered by behavior (e.g., breathing problems). Thus, the RSBQ is an instrument suitable for assessing multiple core RTT features, similar to the MBA. The RSBQ subscale analyses in this study also suggest that, despite its generalized effect, trofinetide may have greater effects on some neurobehavioral symptoms (e.g., mood abnormalities/disruptive behavior). Future studies aiming at replicating the results of this pediatric trial would benefit from including the RSBQ as a primary end point and should also consider evaluating RSBQ subscales such as the General Mood.

While supportive of trofinetide's potential as a treatment for multiple RTT core symptoms, the present study had several limitations. As a phase 2 study, the 2 most obvious are small cohort size and short duration. In addition, no biomarker or clinical characteristic allowed identification of potential responders to trofinetide. Also, as noted above, since weight was a factor moderating exposure, some participants may not have experienced the maximal potential exposure for the dose level they received. Lastly, as this was an exploratory study, we have deemed it appropriate not to include adjustment for multiplicity for the statistical comparisons. Consideration of the above-mentioned factors and the known shortcomings of available outcome measures for $\mathrm{RTT}^{29,41}$ in the design of future trials will be important for their success. RTT is a debilitating and life-threatening neurodevelopmental disorder for which no therapies are available that address its core features. The results presented here provide evidence that trofinetide is a potentially viable treatment for the core signs and symptoms of RTT and support further trials in this population.

\section{Acknowledgment}

The authors thank Rettsyndrome.org for their support of the study and gratefully acknowledge the contribution of patients who participated in the study and their families.

\section{Study funding}

The clinical trial was sponsored by Neuren Pharmaceuticals and funded by Neuren Pharmaceuticals and Rettsyndrome.org.

\section{Disclosure}

D. Glaze was an investigator in the Neuren trofinetide trial reported in this article and the Rett-001 trial of trofinetide in adolescents and adults. He is a consultant to and participates in trials sponsored by Newron Pharmaceuticals SpA. J. Neul was an investigator in the Neuren trofinetide trial reported in this article and the Rett-001 trial of trofinetide in adolescents and adults. He is a consultant to Ovid, AveXis, Eloxx Pharmaceuticals, Biohaven, Teva, and Takeda Pharmaceuticals. He participates in clinical trials sponsored by Newron Pharmaceuticals SpA. W. Kaufmann was part of the study personnel for the Neuren trofinetide trial reported in this article. He is a consultant to Anavex, AveXis, Biohaven, Cydan, Echo, Edison, EryDel, GW Pharmaceuticals, Marinus, Newron Pharmaceuticals SpA, Ovid Therapeutics, Stalicla, and Zynerba. He has been a consultant and participating principal investigator (PI) in sponsor-led trials for Roche, Novartis, and Seaside Therapeutics. Walter Kaufmann was also PI of 2 previous IGF1 (mecasermin) trials in Rett syndrome. He also received research support from Ipsen Pharmaceuticals and Eloxx Pharmaceuticals. E. Berry-Kravis was an investigator in the Neuren trofinetide trial reported in this article and a PI on a Neuren-sponsored trial in fragile X. She is a consultant to Cydan, Fulcrum, GW, Marinus, BioMarin, Zynerba, Yamo, and Neurotrope Pharmaceuticals. She is a consultant and has been a participating PI in sponsor-led trials for Ovid Therapeutics, Alcobra, Roche, Novartis, and Seaside Therapeutics. She receives research support and has been a co-PI of a registration trial for VTS-270 in Niemann-Pick type C 1 for Vtesse/Sucampo/Mallinckrodt. She receives research support from Asuragen Inc. for work on validation of FXS testing methods. S. Condon is a biostatistician for Vital Systems, Inc., a contract research organization utilized by Neuren for the trial described in this article. G. Stoms is president of Vital Systems, Inc., a contract research organization utilized by Neuren for the conduct and analysis of this clinical trial, the Rett-001 trial of trofinetide in adolescents and adults, and trials in fragile $\mathrm{X}$ and traumatic brain injury sponsored by Neuren. S. Oosterholt is a clinical pharmacologist at UCL 
supporting PKPD data analysis for this trial, the Rett-001 trial of trofinetide in adolescents and adults, and trials in fragile $\mathrm{X}$ and traumatic brain injury, sponsored by Neuren Pharmaceuticals Ltd. O. Della Pasqua is chair of Clinical Pharmacology \& Therapeutics Group at the University College London. He is also senior director of Clinical Pharmacology Life Cycle Management at GlaxoSmithKline R\&D, which was not involved with the study. L. Glass is an executive of Neuren Pharmaceuticals. N. Jones is an executive of Neuren Pharmaceuticals. A. Percy was an investigator in the Neuren trofinetide clinical trial reported in this article and Rett-001 trial of trofinetide in adolescents and adults. He is a consultant to Anavex, AveXis, and Teva and participates in trials sponsored by Newron Pharmaceuticals SpA. Go to Neurology.org/N for full disclosures.

\section{Publication history}

Received by Neurology July 28, 2018. Accepted in final form December 19, 2018.

Appendix 1 Authors

\begin{tabular}{|c|c|c|c|}
\hline Name & Location & Role & Contribution \\
\hline $\begin{array}{l}\text { Daniel G. } \\
\text { Glaze, MD }\end{array}$ & $\begin{array}{l}\text { Baylor College of } \\
\text { Medicine, } \\
\text { Department of } \\
\text { Pediatrics and } \\
\text { Neurology }\end{array}$ & Author & $\begin{array}{l}\text { Assisted with the } \\
\text { conceptualization of } \\
\text { the study, enrolled } \\
\text { participants and } \\
\text { collected study data, } \\
\text { interpreted the data, } \\
\text { and critically } \\
\text { reviewed and revised } \\
\text { the manuscript. }\end{array}$ \\
\hline $\begin{array}{l}\text { Jeffrey L. } \\
\text { Neul, MD, } \\
\text { PhD }\end{array}$ & $\begin{array}{l}\text { University of } \\
\text { California, San Diego, } \\
\text { Department of } \\
\text { Neurosciences. } \\
\text { Current affiliation: } \\
\text { Vanderbilt University } \\
\text { Medical Center, } \\
\text { Vanderbilt Kennedy } \\
\text { Center }\end{array}$ & Author & $\begin{array}{l}\text { Assisted with the } \\
\text { conceptualization of } \\
\text { the study, enrolled } \\
\text { participants and } \\
\text { collected study data, } \\
\text { and critically } \\
\text { reviewed and revised } \\
\text { the manuscript. }\end{array}$ \\
\hline $\begin{array}{l}\text { Walter E. } \\
\text { Kaufmann, } \\
\text { MD }\end{array}$ & $\begin{array}{l}\text { Greenwood Genetic } \\
\text { Center, Center for } \\
\text { Translational } \\
\text { Research }\end{array}$ & Author & $\begin{array}{l}\text { Assisted with the } \\
\text { design of the study } \\
\text { and interpretation of } \\
\text { outcome measures, } \\
\text { interpreted the data } \\
\text { and critically } \\
\text { reviewed and revised } \\
\text { the manuscript. }\end{array}$ \\
\hline $\begin{array}{l}\text { Elizabeth } \\
\text { Berry- } \\
\text { Kravis, MD, } \\
\text { PhD }\end{array}$ & $\begin{array}{l}\text { Rush University } \\
\text { Medical Center, } \\
\text { Pediatrics, } \\
\text { Neurological } \\
\text { Sciences, and } \\
\text { Biochemistry }\end{array}$ & Author & $\begin{array}{l}\text { Enrolled participants } \\
\text { and collected study } \\
\text { data, interpreted the } \\
\text { data, and critically } \\
\text { reviewed and revised } \\
\text { the manuscript. }\end{array}$ \\
\hline $\begin{array}{l}\text { Sean } \\
\text { Condon, } \\
\text { DPH }\end{array}$ & Vital Systems, Inc. & Author & $\begin{array}{l}\text { Provided statistical } \\
\text { advice, conducted the } \\
\text { analysis of the safety } \\
\text { and efficacy data, and } \\
\text { reviewed the } \\
\text { manuscript. }\end{array}$ \\
\hline $\begin{array}{l}\text { George } \\
\text { Stoms, BS }\end{array}$ & Vital Systems, Inc. & Author & $\begin{array}{l}\text { Provided statistical } \\
\text { advice, conducted the } \\
\text { analysis of the safety } \\
\text { and efficacy data, and } \\
\text { reviewed the } \\
\text { manuscript. }\end{array}$ \\
\hline
\end{tabular}

Appendix 1 (continued)

\begin{tabular}{|c|c|c|c|}
\hline Name & Location & Role & Contribution \\
\hline $\begin{array}{l}\text { Sean } \\
\text { Oosterholt, } \\
\text { MSc }\end{array}$ & $\begin{array}{l}\text { Clinical Pharmacology } \\
\text { \& Therapeutics } \\
\text { Group, University } \\
\text { College London }\end{array}$ & Author & $\begin{array}{l}\text { Conducted the } \\
\text { pharmacokinetic (PK) } \\
\text { and pharmacokinetic- } \\
\text { pharmacodynamic } \\
\text { (PKPD) analysis, } \\
\text { interpreted the PK } \\
\text { and PKPD data, and } \\
\text { reviewed the } \\
\text { manuscript. }\end{array}$ \\
\hline $\begin{array}{l}\text { Oscar Della } \\
\text { Pasqua, } \\
\text { MD, PhD }\end{array}$ & $\begin{array}{l}\text { Clinical Pharmacology } \\
\text { \& Therapeutics } \\
\text { Group, University } \\
\text { College London }\end{array}$ & Author & $\begin{array}{l}\text { Conducted the } \\
\text { pharmacokinetic (PK) } \\
\text { and pharmacokinetic- } \\
\text { pharmacodynamic } \\
\text { (PKPD) analysis, } \\
\text { interpreted the PK } \\
\text { and PKPD data, and } \\
\text { reviewed the } \\
\text { manuscript. }\end{array}$ \\
\hline
\end{tabular}

Larry Glass, Neuren Author Participated in the

BA Pharmaceuticals, Ltd. conceptualization and design of the study, participated in the analysis, interpreted the data, and critically reviewed and revised the manuscript.

\begin{tabular}{|c|c|c|c|}
\hline $\begin{array}{l}\text { Nancy E. } \\
\text { Jones, PhD }\end{array}$ & $\begin{array}{l}\text { Neuren } \\
\text { Pharmaceuticals, Ltd. }\end{array}$ & Author & $\begin{array}{l}\text { Participated in the } \\
\text { conceptualization } \\
\text { and design of the } \\
\text { study, assisted with } \\
\text { the coordination and } \\
\text { implementation of } \\
\text { the study, } \\
\text { participated in the } \\
\text { analysis, interpreted } \\
\text { the data, and drafted } \\
\text { the manuscript. N.J. } \\
\text { takes responsibility } \\
\text { for the article as } \\
\text { a whole. }\end{array}$ \\
\hline
\end{tabular}

\begin{tabular}{|c|c|c|c|}
\hline $\begin{array}{l}\text { Alan Percy, } \\
\text { MD }\end{array}$ & $\begin{array}{l}\text { University of Alabama } \\
\text { at Birmingham, } \\
\text { Department of } \\
\text { Pediatrics, Division of } \\
\text { Neurology }\end{array}$ & Author & $\begin{array}{l}\text { Alan Percy assisted with } \\
\text { the conceptualization, } \\
\text { design, and } \\
\text { implementation of the } \\
\text { study, enrolled } \\
\text { participants and } \\
\text { collected study data, } \\
\text { interpreted the data, } \\
\text { and critically reviewed } \\
\text { and revised the } \\
\text { manuscript. }\end{array}$ \\
\hline
\end{tabular}

Appendix 2 Coinvestigators

\begin{tabular}{|c|c|c|c|}
\hline Name & Location & Role & Contribution \\
\hline $\begin{array}{l}\text { Arthur } \\
\text { Beisang, MD }\end{array}$ & $\begin{array}{l}\text { Gillette Children's } \\
\text { Specialty } \\
\text { Healthcare }\end{array}$ & $\begin{array}{l}\text { Site } \\
\text { investigator }\end{array}$ & $\begin{array}{l}\text { Enrolled } \\
\text { participants and } \\
\text { collected study } \\
\text { data. Provided } \\
\text { advice on } \\
\text { assessments. }\end{array}$ \\
\hline $\begin{array}{l}\text { Timothy } \\
\text { Benke, MD, } \\
\text { PhD }\end{array}$ & $\begin{array}{l}\text { Children's Hospital } \\
\text { Colorado }\end{array}$ & $\begin{array}{l}\text { Site } \\
\text { investigator }\end{array}$ & $\begin{array}{l}\text { Enrolled } \\
\text { participants and } \\
\text { collected study } \\
\text { data. Provided } \\
\text { advice on } \\
\text { assessments. }\end{array}$ \\
\hline
\end{tabular}


Appendix 2 (continued)

\begin{tabular}{llll}
\hline Name & Location & Role & Contribution \\
\hline $\begin{array}{l}\text { Timothy } \\
\text { Feyma, MD }\end{array}$ & $\begin{array}{l}\text { Gillette Children's } \\
\text { Specialty } \\
\text { Healthcare }\end{array}$ & $\begin{array}{l}\text { Site } \\
\text { investigator }\end{array}$ & $\begin{array}{l}\text { Enrolled } \\
\text { participants and } \\
\text { collected study } \\
\text { data. }\end{array}$ \\
\end{tabular}

\begin{tabular}{|c|c|c|c|}
\hline $\begin{array}{l}\text { Peter } \\
\text { Heydemann, } \\
\text { MD }\end{array}$ & $\begin{array}{l}\text { Rush University } \\
\text { Medical Center }\end{array}$ & $\begin{array}{l}\text { Site } \\
\text { investigator }\end{array}$ & $\begin{array}{l}\text { Enrolled } \\
\text { participants ano } \\
\text { collected study } \\
\text { data. }\end{array}$ \\
\hline
\end{tabular}

\begin{tabular}{llll}
\hline Mary Jones, & UCSF Benioff & Site & Enrolled \\
MD & Children's Hospital & investigator & $\begin{array}{l}\text { participants and } \\
\text { Collected study }\end{array}$ \\
& Oakland & & data
\end{tabular}

data.

\begin{tabular}{llll}
\hline Eric D. & Children's Hospital & Site & Enrolled \\
Marsh, MD, & of Philadelphia & investigator & $\begin{array}{l}\text { participants and } \\
\text { collected study } \\
\text { PhD }\end{array}$ \\
& & data.
\end{tabular}

\begin{tabular}{llll}
\hline Sarika & Vanderbilt & Site & Enrolled \\
Peters, PhD & University Medical & investigator & $\begin{array}{l}\text { participants and } \\
\text { collected study } \\
\text { Center }\end{array}$ \\
& & & data.
\end{tabular}

\begin{tabular}{|c|c|c|c|}
\hline $\begin{array}{l}\text { Myron “Skip" } \\
\text { Peterson, } \\
\text { MD, PhD }\end{array}$ & Cato Research & $\begin{array}{l}\text { Medical } \\
\text { monitor }\end{array}$ & $\begin{array}{l}\text { Monitored and } \\
\text { reviewed safety } \\
\text { data. }\end{array}$ \\
\hline $\begin{array}{l}\text { Mustafa } \\
\text { Sahin, MD, } \\
\text { PhD }\end{array}$ & $\begin{array}{l}\text { Boston Children's } \\
\text { Hospital }\end{array}$ & $\begin{array}{l}\text { Site } \\
\text { investigator }\end{array}$ & $\begin{array}{l}\text { Enrolled } \\
\text { participants and } \\
\text { collected study } \\
\text { data. }\end{array}$ \\
\hline $\begin{array}{l}\text { Steve } \\
\text { Skinner, MD }\end{array}$ & $\begin{array}{l}\text { Greenwood Genetic } \\
\text { Center }\end{array}$ & $\begin{array}{l}\text { Site } \\
\text { investigator }\end{array}$ & $\begin{array}{l}\text { Enrolled } \\
\text { participants and } \\
\text { collected study } \\
\text { data. }\end{array}$ \\
\hline $\begin{array}{l}\text { Shannon } \\
\text { Standridge, } \\
\text { DO, MPH }\end{array}$ & $\begin{array}{l}\text { Department of } \\
\text { Pediatrics, } \\
\text { University of } \\
\text { Cincinnati College } \\
\text { of Medicine, OH; } \\
\text { Division of } \\
\text { Neurology, } \\
\text { Cincinnati } \\
\text { Children's Hospital } \\
\text { Medical Center, OH }\end{array}$ & $\begin{array}{l}\text { Site } \\
\text { investigator }\end{array}$ & $\begin{array}{l}\text { Enrolled } \\
\text { participants and } \\
\text { collected study } \\
\text { data. }\end{array}$ \\
\hline
\end{tabular}

\section{References}

1. Bienvenu T, Philippe C, De Roux N, et al. The incidence of Rett syndrome in France. Pediatr Neurol 2006;34:372-375

2. Laurvick CL, de Klerk N, Bower C, et al. Rett syndrome in Australia: a review of the epidemiology. J Pediatr 2006;148:347-352.

3. Burd L, Vesley B, Martsolf JT, Kerbeshian J. Prevalence study of Rett syndrome in North Dakota children. Am J Med Genet 1991;38:565-568.

4. Hagberg B, Aicardi J, Dias K, Ramos O. A progressive syndrome of autism, dementia, ataxia, and loss of purposeful hand use in girls: Rett's syndrome: report of 35 cases. Ann Neurol 1983;14:471-479.

5. Neul JL, Fang P, Barrish J, et al. Specific mutations in methyl-CpG-binding protein 2 confer different severity in Rett syndrome. Neurology 2008;70:1313-1321.

6. Cuddapah VA, Pillai RB, Shekar KV, et al. Methyl-CpG-binding protein 2 (MECP2) mutation type is associated with disease severity in Rett syndrome. J Med Genet 2014; 51:152-158.

7. Kriaucionis S, Bird A. DNA methylation and Rett syndrome. Hum Mol Genet 2003; 12:R221-R227.

8. Hite $\mathrm{KC}$, Adams VH, Hansen JC. Recent advances in MeCP2 structure and function. Biochem Cell Biol 2009;87:219-227.

9. Neul JL, Kaufmann WE, Glaze DG, et al; for the RettSearch Consortium. Rett syndrome: revised diagnostic criteria and nomenclature. Ann Neurol 2010;68:946-951.

10. Percy A. Rett syndrome: coming to terms with treatment. Adv Neurosci 2014;2014: $1-20$.
11. Urbanowicz A, Downs J, Girdler S, Ciccone N, Leonard H. Aspects of speechlanguage abilities are influenced by MECP2 mutation type in girls with Rett syndrome. Am J Med Genet A 2015;167:354-362.

12. Kaufmann WE, Tierney E, Rohde CA, et al. Social impairments in Rett syndrome: characteristics and relationship to clinical severity. J Intellect Disabil Res 2012;56: 233-247.

13. Cianfaglione R, Clarke A, Kerr M, et al. National survey of Rett syndrome: behavioural characteristics. J Neurodev Disord 2015;7:11-15.

14. Barnes K, Coughlin FR, O'Leary HM, et al. Anxiety-like behaviour in Rett syndrome: characteristics and assessment by anxiety scales. J Neurodev Disord 2015;7:30.

15. Kirby RS, Percy AK, Lane JB, et al. Longevity in Rett syndrome: probing the North American Database. J Pediatr 2010;159:135-138.

16. Tarquinio DC, Hou W, Neul JL, et al. The changing face of survival in Rett syndrome and MECP2-related disorders. Pediatr Neurol 2015;53:402-411.

17. Tropea D, Giacometti E, Wilson NR, et al. Partial reversal of Rett syndrome-like symptoms in MeCP2 mutant mice. Proc Natl Acad Sci USA 2009;106: 2029-2034.

18. Derecki NC, Cronk JC, Lu Z, et al. Wild-type microglia arrest pathology in a mouse model of Rett syndrome. Nature 2012;484:105-109.

19. Lu XC, Si Y, Williams AJ, Hartings JA, Gryder D, Tortella FC. NNZ-2566, a glypromate analog, attenuates brain ischemia-induced non-convulsive seizures in rats. J Cereb Blood Flow Metab 2009;29:1924-1932.

20. Wei HH, Lu XC, Shear DA, et al. NNZ-2566 treatment inhibits neuroinflammation and pro-inflammatory cytokine expression induced by experimental penetrating ballistic-like brain injury in rats. J Neuroinflammation 2009;6:19.

21. Glaze DG, Neul JL, Percy A, et al. A double-blind, randomized, placebo-controlled clinical study of trofinetide in the treatment of Rett syndrome. Pediatr Neurol 2017; 76:37-46.

22. Oosterholt SP, Horrigan J, Jones N, Glass L, Della PO. Population pharmacokinetics of NNZ-2566 in healthy subjects. Eur J Pharm Sci 2017;109:S98-S107.

23. Percy A, Neul J, Glaze D, et al. Rett syndrome diagnostic criteria: lessons from the Natural History Study. Ann Neurol 2010;68:951-955.

24. Neul JL, Lane JB, Lee HS, et al. Developmental delay in Rett syndrome: data from the Natural History Study. J Neurodev Dis 2014;6:2-9.

25. FitzGerald PM, Jankovic J, Percy AK. Rett syndrome and associated movement disorders. Mov Disord 1990;5:195-202.

26. Neul JL, Glaze DG, Percy A, et al. Improving treatment trial outcomes for Rett syndrome: the development of Rett-specific anchors for the Clinical Global Impression Scale. J Child Neurol 2015;30:1743-1748.

27. Mount RH, Charman T, Hastings RP, Reilly S, Cass H. The Rett Syndrome Behaviour Questionnaire (RSBQ): refining the behavioural phenotype of Rett syndrome. J Child Psychol Psych 2002;43:1099-1110.

28. Khwaja OS, Ho E, Barnes KV, et al. Safety, pharmacokinetics, and preliminary assessment of efficacy of mecasermin (recombinant human IGF-1) for the treatment of Rett syndrome. Proc Natl Acad Sci USA 2014;111:4596-4601.

29. Katz DM, Bird A, Coenraads M, Gray SJ, Menon DU, Philpot BD, Rett syndrome: crossing the threshold to clinical translation. Trends Neurosci 2016;39:100-113.

30. Cianfaglione R, Clarke A, Kerr M, Hastings RP, Oliver C, Felce D. Ageing in Rett syndrome. J Intellect Disabil Res 2016;60:182-190.

31. O'Leary HM, Kaufmann WE, Barnes KV, et al. Placebo controlled crossover efficacy assessment of mecasermin for the treatment of Rett syndrome. Ann Clin Transl Neurol 2018;5:323-332.

32. Robertson L, Hall SE, Jacoby P, Ellaway C, de Klerk N, Leonard H. The association between behaviour and genotype in Rett syndrome using the Australian Rett Syndrome Database. Am J Med Genet 2006;141:177-183.

33. Arnold LE, Vitiello B, McDougle C, et al. Parent-defined target symptoms respond to risperidone in RUPP Autism Study: customer approach to clinical trial. J Am Acad Child Adolesc Psychiatry 2003;42:1443-1450.

34. Turner EH, Matthews AM, Linardatos E, Tell RA, Rosenthal R. Selective publication of antidepressant trials and its influence on apparent efficacy. N Engl J Med 2008;358: 252-260.

35. Corvin AP, Molinos I, Little G, et al. Insulin-like growth factor 1 (IGF1) and its active peptide (1-3)IGF1 enhance the expression of synaptic markers in neuronal circuits through different cellular mechanisms. Neurosci Lett 2012;520:51-56.

36. Taneja A, Oosterholt SP, Danhof M, Della Pasqua O. Biomarker exposure-response relationships as the basis for rational dose selection: lessons from a simulation exercise using a selective COX-2 inhibitor. J Clin Pharmacol 2016;56:609-621.

37. Danhof M, Alvan G, Dahl SG, Kuhlmann J, Paintaud G. Mechanism-based pharmacokinetic-pharmacodynamic modeling: a new classification of biomarkers. Pharm Res 2005;22:1432-1437.

38. Piana C, Zhao W, Adkison $\mathrm{K}$, et al. Covariate effects and population pharmacokinetics of lamivudine in HIV-infected children. Br J Clin Pharmacol 2014;77:861-872.

39. Cella M, Knibbe C, Danhof M, Della Pasqua O. What is the right dose for children? $\mathrm{Br}$ J Clin Pharmacol 2010;70:597-603.

40. Cella M, Danhof M, Della Pasqua O. Adaptive trials in paediatric development: dealing with heterogeneity and uncertainty in pharmacokinetic differences in children. Br J Clin Pharmacol 2012;74:346-353.

41. Kaufmann WE, Stallworth JL, Everman DB, Skinner SA. Neurobiologically-based treatments in Rett syndrome: opportunities and challenges. Expert Opin Orphan Drugs 2016;4:1043-1055. 


\section{Neurology}

\section{Double-blind, randomized, placebo-controlled study of trofinetide in pediatric Rett syndrome}

Daniel G. Glaze, Jeffrey L. Neul, Walter E. Kaufmann, et al.

Neurology 2019;92;e1912-e1925 Published Online before print March 27, 2019

DOI 10.1212/WNL.0000000000007316

This information is current as of March 27, 2019

\section{Updated Information \& Services}

References

Citations

Subspecialty Collections

Permissions \& Licensing

Reprints including high resolution figures, can be found at: http://n.neurology.org/content/92/16/e1912.full

This article cites 41 articles, 4 of which you can access for free at: http://n.neurology.org/content/92/16/e1912.full\#ref-list-1

This article has been cited by 2 HighWire-hosted articles: http://n.neurology.org/content/92/16/e1912.full\#\#otherarticles

This article, along with others on similar topics, appears in the following collection(s):

All Clinical Neurology

http://n.neurology.org/cgi/collection/all_clinical_neurology

All Clinical trials

http://n.neurology.org/cgi/collection/all_clinical_trials

All Pediatric

http://n.neurology.org/cgi/collection/all_pediatric

Clinical trials Randomized controlled (CONSORT agreement)

http://n.neurology.org/cgi/collection/clinical_trials_randomized_contro

lled_consort_agreement

Rett Syndrome

http://n.neurology.org/cgi/collection/rett_syndrome

Information about reproducing this article in parts (figures,tables) or in its entirety can be found online at:

http://www.neurology.org/about/about_the_journal\#permissions

Information about ordering reprints can be found online:

http://n.neurology.org/subscribers/advertise

Neurology ${ }^{\circledR}$ is the official journal of the American Academy of Neurology. Published continuously since 1951, it is now a weekly with 48 issues per year. Copyright Copyright ( 2019 The Author(s). Published by Wolters Kluwer Health, Inc. on behalf of the American Academy of Neurology.. All rights reserved. Print ISSN: 0028-3878. Online ISSN: 1526-632X.

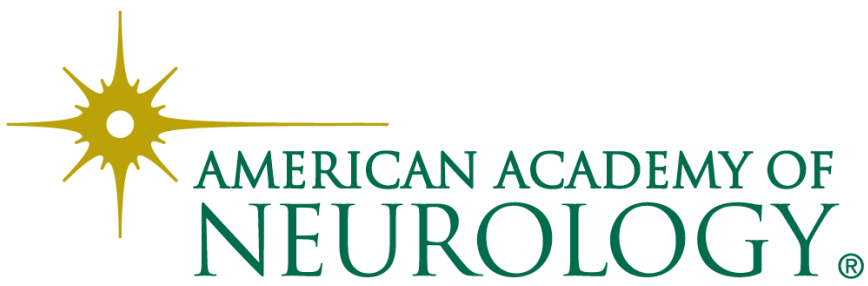

